\title{
Chapter 9 \\ When the IOM Speaks: IOM Quality \\ of Care Committee and Report
}

On July 7, 1998, I received an invitation from the Institute of Medicine (IOM) to become a member of the Committee on Quality of Health Care in America. The Committee, chaired by Bill Richardson of the Kellogg Foundation, was an outgrowth of an IOM Roundtable on Quality of Care, chaired by Mark Chassin and Robert Galvin.

I was initially reluctant. I had been on several IOM committees by then. Although the quality of their work was impressive, it took a lot of time, and few of the reports seemed to have wide circulation or impact. I called them "shelf research." I wasn't sure I wanted to participate in another.

However, when the staff person calling, Molla Donaldson, told me who else was on the committee - a veritable who's who of quality and policy leadership-I decided to join, if for no other reason than to get to know some people whom I admired. I didn't realize at the time that medical error would be a key focus and that I was a key resource for that. And I certainly had no inkling how much of an impact our work would ultimately have. "Shelf research" indeed!

The IOM Committee on Quality of Health Care in America took its origin from a series of efforts over the previous decade that documented serious problems in healthcare quality. These included a steady stream of research from RAND showing major quality of care shortcomings, the report from the Presidential Advisory Commission on Consumer Protection and Quality in the Health Care Industry [1], 
the findings of the IOM National Roundtable on Health Care Quality [2], and the Milbank Memorial Fund Quarterly Review of evidence of poor quality of healthcare [3].

The Presidential Advisory Commission, appointed by the Clinton administration in 1997 and co-chaired by Donna Shalala, secretary of Health and Human Services, and Alexis Herman, secretary of the Department of Labor, had special weight. The president was concerned about healthcare and especially about the quality implications of "managed care," and he appointed a blue-ribbon committee that included consumers, representatives from business, labor, healthcare providers, health plans, state and local governments, and healthcare quality experts, to insure broad input.

The Advisory Commission's 1998 report, "Quality First: Better Healthcare for All Americans," brought together the evidence for quality problems and the broad consensus for reform [1]. It concluded that quality problems were pervasive and by no means confined to managed care systems. The report was aimed at Congress and policymakers in Washington and made clear recommendations, including a call for a "Patient Bill of Rights," which the Clinton administration enacted. Otherwise, even though it got a lot of attention, the report resulted in little action.

Enter Steve Schroeder, president of the Robert Wood Johnson Foundation (RWJ). Deeply concerned about the quality of healthcare and anxious to capitalize on the growing pressure for action, Schroeder consulted with Ken Shine, president of the IOM, about moving ahead. Shine was enthusiastic. RWJ gave two million dollars to the IOM to establish the Quality of Care in America Committee. Shine took the unusual step of putting in additional funds from the IOM. Normally, IOM projects were commissioned and funded by Congress or an Executive Branch Agency.

To secure strong leadership, Shine reached out to Bill Richardson, president and CEO of the Kellogg Foundation, to serve as the chair and Janet Corrigan, executive director of the President's Advisory Commission on Consumer Protection and Quality (which was coming to a close), to serve as the project director.

As the project was beginning to take shape, two issues became clear. First, it should "pick up the baton" from the earlier work. Toward 

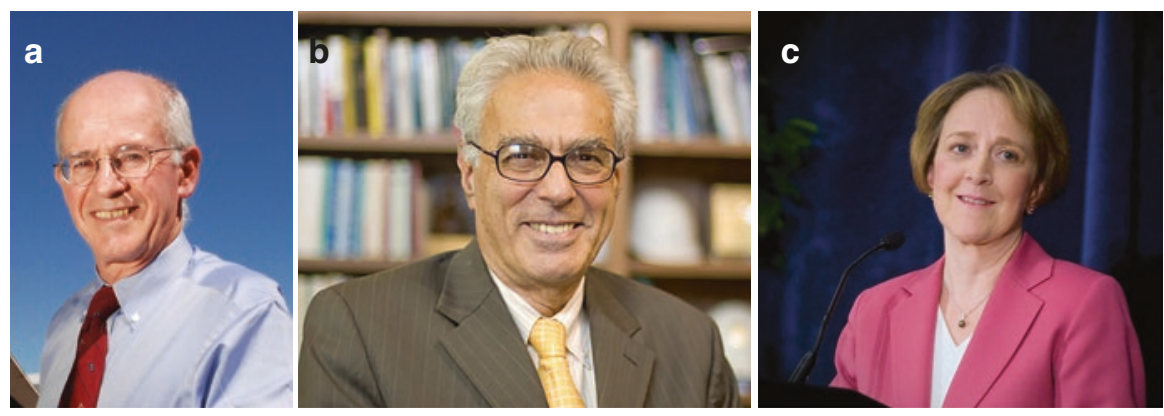

(a) Steve Schroeder, (b) Ken Shine, and (c) Janet Corrigan. (All rights reserved)

this end, the committee was populated with some of the experts who had served on the earlier IOM Roundtable and the President's Advisory Commission.

Second, it would be important to obtain a much deeper understanding of why earlier efforts had fallen on deaf ears and to identify ways to overcome what appeared to be communication barriers.

Accordingly, one of the first activities it undertook was to convene a workshop of people from print and broadcast media and pose the question of how to most effectively get public attention to quality information. Their advice was to keep it simple - things that people can understand - and to frame the issue in terms of a victim and a villain. The obvious candidate: patient safety. Just as plane accidents are understandable, so are medical mishaps. The victims are people just like us; and there was a villain: a defective health care system.

A focus on safety might also enlist the support of the medical profession, which had become defensive about efforts to improve quality. When challenged, doctors would typically counter with "My patients are different." Perhaps shifting the focus to defective systems would bring them aboard.

Safety had another appeal: a movement to do something about it was already underway. The Annenberg Conference had been convened 2 years earlier, sponsored by the AMA, The Joint Commission, and the American Association for the Advancement of Science. The AMA had created the National Patient Safety Foundation, The Joint Commission had strengthened its sentinel events reporting system, and Don Berwick's IHI had conducted a collaborative aimed at reducing medication errors. 
The safety problem had been defined, and efforts to change systems had begun. Despite this, most Americans, and most medical professionals, were still unaware and uninvolved. This was a big opportunity to do something about that.

So it was decided that the Quality of Care in America Committee would focus on both quality and safety but lead with safety to get public and political attention. Two subcommittees were formed: one on the environment of healthcare (which focused on patient safety) and the other on structure (which David Lawrence, head of Kaiser Permanente, had nicknamed the "chassis"). The committees would meet separately and together. I was on the environment subcommittee, chaired by Chris Bisgard, director, Health Services, Delta Air Lines, and Molly Joel Coye of the Lewin Group. Don Berwick chaired the "chassis" one. Don and Dave Lawrence were on both. The first meeting was September 28. Members of the committee are listed in Appendix 9.1.

At the January 1999 meeting of subcommittee on the environment, we focused on reporting of medical errors. Charles Billings, architect of the aviation reporting system, told us that reporting systems don't work unless they are safe, simple, and productive. Safe: the reporter must not be at risk of losing their job or being disciplined for reporting a mistake they have made. Simple: people will not report if the process is too complicated (a long form) or takes too much time. Productive: reporting must lead to a response by the organization to address the issue reported. If nothing happens after people report, they lose interest and stop reporting. We would embrace these concepts in the final report's recommendations for reporting.

At the February meeting of the whole committee, Don Berwick led a discussion of values. He presented six "Aims for Improvement" that he had proposed at an earlier "chassis" committee meeting in Woods Hole: that care should be safe, effective, patient-centered, timely, efficient, and equitable. The aims resonated with all and were quickly embraced. They became the centerpiece of the recommendations in the final report, Crossing the Quality Chasm.

Berwick's six aims have proved not only to be most memorable part of the report but also the most powerful. Easily understood, intuitively important, and actionable, they became the framework for 
thinking about and acting on quality improvement that has motivated practice and research for more than 20 years.

At the March 18 joint meeting of the subcommittees, Berwick presented another organizing concept: the "Chain of Effect" model that shows the relationships among patient and community/microsystem/ organization/environment (policy). Don explained the microsystems concept: It is the level—hospital unit or office-where care is given.

Jim Reinertson, CEO of Minnesota HealthPartners, noted that doctors often think they are held accountable as individuals for harm that is actually caused by systems failures. He urged that we not pit professionalism against systems but join them together. All agreed that complexity is a big cause of errors.

We also agreed that we needed better definitions of safety and systems; many are too theoretical. Berwick noted that "standards" can mean three different things: performance standards (desired or expected results), process standards (the agreed way to do things), and measures (such as the "standard kilogram"). All are important, but we needed to explain and distinguish among them.

In April we held a communications workshop. This content-filled meeting was designed both to bring the committee up to date on technological advances and to get advice on how to communicate our findings. Bob Blendon reminded us that the best way to influence the public is to combine a personal case of harm with a villain and a solution.

We agreed that we had to get the public aroused to get the system to change. The definition of poor quality for many people was that your HMO is not letting you get the care you think you need. Some noted that the problem isn't communication, but it is whether the institution responds or doesn't. What is our overall strategy for improving quality? What is our media strategy for making that happen?

Other guest speakers talked about the role of new technologies, such as computerized physician order entry and computerized patient records. I will never forget Joe Scherger's comments. Joe was a primary care doctor who was also associate dean for clinical affairs, at UC Irvine. He made a brief but powerful talk that he summarized by saying that there was one simple thing a physician could do that would simultaneously save time, improve communication, and improve patient satisfaction: "Give your patients your email address." 
Reflecting on this as a patient 20 years later, I am struck both with how true it is and how difficult it still seems to be for doctors to do it!

At the April meeting following the communications workshop, we developed the strategy for advancing our recommendations: (1) a broad-based communication strategy involving prominent figures, dissemination of credible data, and gaining access to policy-makers; (2) pressure for public-private-regulatory initiatives, such as quality of care forums, and (3) advocacy for building trust-building actions into healthcare, i.e., open communication when things go wrong.

I made the case for putting less emphasis on mandatory systems for reporting and greater emphasis on developing response systems, as recommended by Billings. For example, both USP and ISMP reporting systems identify risks related to naming, packaging, dosing, and use of medications, but the FDA and pharmaceutical industry are slow to respond or don't so at all. State reporting systems are often "black holes."

Don Berwick called for developing illustrative cases-how we do it now, how we should do it using the systems approach, and full root cause analysis. Chris Bisgard noted that the lack of a defibrillator in a single case of cardiac arrest on a Delta flight led airlines to install them on all planes, despite the fact that the cardiac arrest rate was 8 in 50 million!

What policies do we want adopted? One person called for going after the $1 \%$ of doctors who are negligent by improving state board functioning. The Committee did not want to do that. We had an extensive discussion about the advisability of having an FAA equivalent for healthcare. I came down strongly on the side of yes, but that proved to be a step too far for the committee. We did agree to press for a federal agency to oversee safety and to change the reimbursement system from pay for volume to pay for quality.

Our discussions were coming to a close. There would be two reports: one on safety and one on quality of care. The safety report would be aimed at a broad audience: both healthcare professionals and the general public. The report on quality (Crossing the Quality Chasm) would be targeted to healthcare professionals and would spell out the theoretical concepts and details of what was needed to improve quality of care overall, based on the six aims. 
The safety report would be published first since it would grab public and professional attention with its shocking numbers and "victim, villain, solution." Corrigan and her staff were nearing completion; drafts were circulated, and committee members made edits or rewrote substantial segments.

\section{To Err Is Human}

The report was titled To Err Is Human [4]. It "made the case" for patient safety, explaining the science of error-making and the theoretical and practical evidence for human-factors-based systems changes. In many ways it was an expansion of the ideas set forth in my 1994 paper, Error in Medicine, but it provided more detailed descriptions of methods and provided case studies to illustrate the points.

In addition to documenting the need for attention to the issue of patient safety, To Err Is Human explained the concept of using a systems approach based on human factors principles and proclaimed that application of this methodology could have a profound effect. It boldly called for a 50\% reduction in medical harm in 5 years.

Specific recommendations were made to galvanize the healthcare industry into action to improve safety. The recommendations were nicely summarized in a later report of the Presidential Quality Interagency Task Force [5], excerpts from which I quote here, with my comments in italics:

Establish a Center for Patient Safety at the Agency for Healthcare Research and Quality (AHRQ) with responsibility for promoting the development of knowledge about errors and to encourage the sharing of strategies for reducing errors. The IOM committee recommends substantial budget increases over the next several years. (This was the most important recommendation. To move ahead in patient safety, we had to have central leadership and funding. Patient safety had to be a national priority.)

Promote voluntary and mandatory reporting of errors. First, the IOM recommends that voluntary reporting systems should focus on errors that result in little or no harm to patients and should be 
encouraged by AHRQ. Second, a mandatory reporting system should be established to allow state governments to collect standardized information on adverse events resulting in death or serious harm. (Increased reporting was something everyone thought was important. I was not so sure. (See Chap. 17.) But the idea of having a voluntary system to spur improvement and a mandatory system for accountability did make sense.)

Protect reporting systems from being used in litigation. The IOM urges Congress to pass legislation extending peer review protections to data related to patient safety and quality improvement that are collected and analyzed by healthcare organizations for purposes of improving safety and quality. (We all agreed this was essential if we were ever to get people to talk about error in the current litigious environment.)

Make patient safety the focus of performance standards for healthcare organizations and professionals. Regulators and accreditors should require healthcare organizations to have meaningful patient safety programs. Purchasers are also encouraged to provide incentives for patient safety programs. The IOM suggests that professional licensing organizations periodically reexamine and relicense professionals based, in part, on their knowledge of patient safety.

Licensing organizations also need to develop more effective means of identifying unsafe practitioners and taking actions against them. It also suggests that professional societies should promote patient safety education. (This was our pitch that safety is everyone's business. Healthcare organizations, professional societies, and regulators had to step up.)

Increase FDA attention to safety in pre- and post-market reviews of drugs. The IOM specifically suggests developing standards for safe packaging and labeling; testing of drug names to prevent sound-alike and look-alike errors; and working with doctors, pharmacists, and patients to identify and rectify problems in the post-marketing phase. (The failure of the FDA to do this was, we thought, unconscionable. They and the manufacturers knew these were problems and looked the other way. It was time to stop.)

Encourage healthcare organizations to make a commitment to improving patient safety and to implement safe medication practices. Healthcare organizations should develop a culture of safety and 
implement nonpunitive systems for reporting and analyzing errors. These organizations should also follow recommendations for safe medication practices as published by professional and collaborative organizations interested in patient safety. (Of course! The culture had to change. Making that happen would turn out to be the major challenge, still unresolved (Chap. 23)).

Because the error report was expected to attract public interest and garner attention for the whole quality effort, chairman Richardson and staff director Corrigan decided that it should be released first, and the sooner the better. The report was scheduled to be released on Wednesday, December 1, 1999, so staff made an embargoed copy of the report available to elite media ahead of time and planned for a press conference on the 1st. Then things went awry.

On Monday afternoon, November 29, Don Berwick and I were called by IOM staff and asked to come to Washington immediately. A major television network had decided to break the embargo and go with the story on that night's news. The other networks quickly found out, so all of them were going to be doing the story that evening. The IOM decided to release the report immediately but wanted Don and me to come down for interviews on these national networks that evening.

It was a bit of a circus. I was sent to one network and Don to another, and then we each went to a second. It was hot news, but fortunately the stories were reasonably faithful, and the interviews were on point and not over-sensationalized. What got attention was the estimate that there were up to 98,000 preventable deaths a year due to medical errors. That number also headlined the newspaper stories the next day. In all fairness, the news reports did note that these errors and deaths were due to systems failures, but most viewers and readers were so stunned by 98,000 that it was lost in the uproar.

The 98,000 number was actually a last minute extrapolation that Janet Corrigan made by updating to the present the number of preventable deaths estimated by the Medical Practice Study 9 years earlier, which was over 120,000 [6]. In the interim, thanks to managed care and other cost-cutting measures, the number of patients hospitalized had dropped considerably. One could argue that these were sicker patients, so the number of injuries might not have dropped proportionately, but no matter, 98,000 was shocking enough. 
The IOM had never seen anything like it. As I later noted in a NEJM editorial, "The speed and intensity with which the IOM report captured media, public, political, and professional attention surprised everyone. Neither the shocking statistics nor its central message, that errors are caused by faulty systems, was new, but the report forcefully brought them to public awareness." [7] In talks about the report later I would parody a financial house ad, "When researchers speak, no one listens, when the IOM speaks, everyone listens."

In truth, they hadn't listened to the IOM much before, either, of course, but this was different. To Err Is Human was by far the most widely disseminated and commented on report ever issued by the IOM, a record that still stands 20 years later. A later survey showed that $51 \%$ of Americans were aware of the report, which was unprecedented. Skeptics have argued that we got so much coverage because it was a slow news day. While that may be true, it was also true that the message was powerful and touched everyone. If the timing was good luck, fine. The cause deserved it!

Within days, Congress scheduled hearings, and president Clinton formed the Quality Interagency Task Force-headed, fortunately, by John Eisenberg, administrator of the newly formed Agency for Healthcare Research and Quality (AHRQ) — to analyze the report and make recommendations. The administration — the president, secretary Shalala, and Chris Jennings, the health policy advisor-all wanted to do something, so they acted quickly in response.

The formation of the Task Force was announced by the president at a press conference in the Rose Garden. A number of us were invited to attend. I remember well the tingle that went up my spine, and I gave a silent "Hooray!" when I heard the president of the USA mouth our mantra: "It's not bad people, it's bad systems." Sixty days later, when the Task Force made its recommendations [5], the president called on all federal health agencies to implement the IOM recommendations. The IOM had accomplished an unprecedented act of agenda setting.

The report's shocking numbers and the recognition that errors are caused by faulty systems came from our earlier work, but the IOM report brought them to public and policy-makers attention in a way that those of us devoted to patient safety had been unable to do. Of course I was delighted. As the patient safety expert member of the 
IOM committee, it fell to me to be a lead spokesperson for the IOM and an unprecedented opportunity to influence public policy.

The Annenberg Conference in 1996 brought the research and advocacy communities together for the first time to focus on patient safety, but it was the IOM report that brought it to the attention of the public and the medical profession.

The IOM report started the patient safety movement.

\section{Postscript}

Fallout from the IOM report was not all positive. Predictably, many physicians took umbrage. They were insulted by what they saw as the implication they were not doing their job properly. A number began to question the numbers. I found this particularly ironic, since none of these objections had been raised 9 years earlier when we published the MPS results. In fact, we were very disappointed at the time with the paucity of reactions!

Over the next year or two, multiple papers were published "proving" our numbers were inflated. We knew, of course, that they were underestimates (see Chap. 1). In fact, ultimately a number of later studies corroborated that, revealing adverse event rates that were 2-4 times what we found [8-11].

Several of the negative papers deserve comment. One from the VA "reanalyzed" our data (without consulting us) and claimed that most of the people who died would have died anyway [12]. Leaving aside the methodologic errors behind this conclusion, its moral repugnancy seemed to have escaped the authors: the implication that it's all right to make fatal mistakes on seriously ill patients!

A more interesting assault came from Clem McDonald and colleagues at the University of Indiana who also "reanalyzed" our dataagain without consulting us-using our screening criteria as risk factors to calculate "excess mortality." [13] The fallacy of this approach was so obvious that I was surprised that JAMA would publish it. To its credit, the editor asked me to comment and put the two papers in the "Controversies" section.

I explained why screening criteria cannot be used as risk factors: Risk factors are characteristics that increase the likelihood of a future 
outcome; e.g., the presence of diabetes increases the likelihood of developing a myocardial infarct. Screening criteria are indicators of an outcome that has already occurred. A myocardial infarction indicates that a patient could have diabetes, but it does not prove it or cause the diabetes. Risk factors look to the future, and screening factors examine the past [14].

Sadly, their paper also looked at "excess" mortality. I rebutted this directly with the analysis from our study that $86 \%$ of the preventable deaths occurred in patients who were not terminal and for whom the error was the major factor leading to their deaths.

An interesting sidebar to this discussion was that Katie Couric of NBC's Today decided to interview the two of us on TV. I told her that I was on vacation in Vermont and could not come to New York. No problem: they sent the TV crew to us and interviewed me in our living room in Newfane, VT!

I took some delight in catching her and McDonald unawares by opening my remarks with praise for his work as a pioneer in the application of computers to medicine. My compliment was sincere: Clem had made significant contributions. The look on Katie's face was priceless. I then went on to say that in this case unfortunately he was wrong and explained the difference between risk factors and screening criteria. I don't remember what Clem said, but I came away feeling we won that one.

But the critique that hurt came from my colleague and co-author of the MPS, Troy Brennan. Troy was not enamored of my work on error, particularly disclosure. He firmly believed that it would lead to more malpractice suits. In a paper in The New England Journal of Medicine, he took aim at the IOM report's preventability numbers, which were derived from our study! [15] He debunked our conclusions, asserting that we had not asked about error in the MPS, which was not true [16]. Whether this was intentional or an honest mistake, I don't know. What saddened me, though, was that he never discussed it with me or gave me-his co-author on the study-an opportunity ahead of time to review his paper. I first learned about it when I read my copy of NEJM.

I spoke to the editor, Marcia Angell, about the fact that the paper included a falsehood and asked her to publish my rebuttal. She refused, suggesting instead that I submit a letter to the editor! Before doing so, I consulted with Bill Richardson, chair of the IOM committee, and we 
agreed that I should write the response, but it would have greater impact coming from the committee. We pointed out the error and also why our estimate of the number of preventable injuries was not an exaggeration [17].

After this flurry of debunking reports in 2000, the academic chatter quieted down, and the serious effort to make healthcare safe began. The problem was, unhappily, worse than our numbers had indicated. But the IOM report got us moving.

\section{Appendix 9.1: Committee on Quality Of Health Care In America}

William C. Richardson, Chair, President and CEO, W.K. Kellogg Foundation, Battle Creek, MI.

Donald M. Berwick, President and CEO, Institute for Healthcare Improvement, Boston, MA.

J. Cris Bisgard, Director, Health Services, Delta Air Lines, Inc., Atlanta, GA.

Lonnie R. Bristow, Past President, American Medical Association, Walnut Creek, CA.

Charles R. Buck, Program Leader, Health Care Quality and Strategy Initiatives, General Electric Company, Fairfield, CT.

Christine K. Cassel, Professor and Chairman, Department of Geriatrics and Adult Development, Mount Sinai School of Medicine, New York, NY.

Mark R. Chassin, Professor and Chairman, Department of Health Policy, Mount Sinai School of Medicine, New York, NY.

Molly Joel Coye, Senior Vice President and Director, The Lewin Group, San Francisco, CA.

Don E. Detmer, Dennis Gillings Professor of Health Management, University of Cambridge, UK.

Jerome H. Grossman, Chairman and CEO, Lion Gate Management Corporation, Boston, MA.

Brent James, Executive Director, Intermountain Health Care, Institute for Health Care Delivery Research, Salt Lake City, UT. 
David McK. Lawrence, Chairman and CEO, Kaiser Foundation Health Plan, Inc., Oakland, CA.

Lucian Leape, Adj. Professor of Health Policy, Harvard School of Public Health, Boston, MA.

Arthur Levin, Director, Center for Medical Consumers, New York, NY. Rhonda Robinson-Beale, Executive Medical Director, Managed Care Management and Clinical Programs, Blue Cross Blue Shield of Michigan, Southfield. MI.

Joseph E. Scherger, Associate Dean for Clinical Affairs, University of California, Irvine, CA.

Arthur Southam, Partner, 2C Solutions, Northridge, CA.

Mary Wakefield, Director, Center for Health Policy and Ethics, George Mason University, Washington, D.C.

Gail L. Warden, President and CEO, Henry Ford Health System, Detroit, MI.

\section{References}

1. The President's Advisory Commission on Consumer Protection and Quality in the Health Care Industry. Quality first: better health care for all Americans. 1998.

2. Chassin MR, Galvin RW. The urgent need to improve health care quality. Institute of Medicine National Roundtable on Health Care Quality [see comments]. JAMA. 1998;280:1000-5.

3. Schuster MA, McGlynn EA, Brook RH. How good is the quality of health care in the United States? Milbank Q. 1998;76:517-63.

4. Kohn KT, Corrigan JM, Donaldson MS, editors. To err is human: building a safer health system. Washington, DC: National Academy Press; 1999.

5. QuIC. Doing what counts for patient safety. Federal actions to reduce medical errors and their impact. Washington, DC: AHRQ; 2000 February.

6. Leape LL, Lawthers AG, Brennan TA, Johnson WG. Preventing medical injury. Qual Rev Bull. 1993;19:144-9.

7. Leape LL, Epstein AM, Hamel MB. A series on patient safety. NEJM. 2002;347:1272-4.

8. HHS Office of Inspector General. In: Services DoHaH, editor. Adverse events in hospitals: national incidence among Medicare beneficiaries. Washington, D.C: Department of Health and Human Services, Office of Inspector General; 2010:i-iv. p. 1-74. 
9. Landrigan CP, Parry GJ, Bones CB, Hackbarth AD, Goldmann DA, Sharek PJ. Temporal trends in rates of patient harm resulting from medical care. NEJM. 2010;363:2124-34.

10.Classen DC, Resar R, Griffin F, et al. 'Global Trigger Tool' shows that adverse events in hospitals may be ten times greater than previously measured. Health Aff. 2011;30:581-9.

11. Makary MA, Daniel M. Medical error - the third leading cause of death in the US. BMJ. 2016;353:i2139.

12.Hayward RA, Hofer TP. Estimating hospital deaths due to medical errors: preventability is in the eye of the reviewer. JAMA. 2001;286:415-20.

13. McDonald CJ, Weiner M, Hui SL. Deaths due to medical errors are exaggerated in Institute of Medicine Report. JAMA. 2000;284:93-5.

14.Leape LL. Institute of Medicine Medical error figures are not exaggerated. JAMA. 2000;284:95-7.

15. Brennan TA. The Institute of Medicine report on medical errors - could it do harm? NEJM. 2000;342:1123-5.

16.Leape LL, Brennan TA, Laird NM, et al. The nature of adverse events in hospitalized patients: results from the Harvard Medical Practice Study II. New Eng J Med. 1991;324:377-84.

17. Richardson WC, Berwick DM, Bisgard JC. Correspondence: The Institute of Medicine report on medical errors. NEJM. 2000;343:663-5. 
Open Access This chapter is licensed under the terms of the Creative Commons Attribution 4.0 International License (http://creativecommons.org/ licenses/by/4.0/), which permits use, sharing, adaptation, distribution and reproduction in any medium or format, as long as you give appropriate credit to the original author(s) and the source, provide a link to the Creative Commons license and indicate if changes were made.

The images or other third party material in this chapter are included in the chapter's Creative Commons license, unless indicated otherwise in a credit line to the material. If material is not included in the chapter's Creative Commons license and your intended use is not permitted by statutory regulation or exceeds the permitted use, you will need to obtain permission directly from the copyright holder.

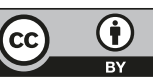

